\title{
Rumah Panjang: Nilai Edukasi Dan Sosial Dalam Sebuah Bangunan Vernakular Suku Dayak Di Kalimantan Barat
}

\author{
Affrilyno \\ Program Studi S2 Teknik Arsitektur dan Perencanaan Universitas Gadjah Mada. \\ Email : berkarat999@yahoo.com \\ Pembimbing:Prof. Ir. Nindyo S, M. Phil, Ph. D
}

\begin{abstract}
ABSTRAK
Rumah panjang merupakan bentuk arsitektur vernakular yang khas dari masyarakat suku Dayak di Kalimantan. Saat ini rumah panjang tengah menghadapi arus modernisasi dan semakin lama semakin berkurang jumlahnya. Dalam kehidupan sehari-hari, rumah panjang merupakan tempat bagi suku Dayak melakukan segala aktivitas bersama, berinteraksi, belajar kepada kaum tua dan menurunkan berbagai kebijaksanaan tradisional (traditional wisdom), pengetahuan asli (indigenous knowledge) orang Dayak. Secara singkat, rumah panjang adalah pusat segala aktivitas sosial, budaya, edukasi, ekonomi dan politik masyarakat suku Dayak. Rumah panjang adalah pusat kebudayaan bagi masyarakat suku Dayak. Maka Rumah panjang merupakan jantung kehidupan masyarakat suku Dayak. Permasalahan yang dikaji adalah rumah panjang terkait dengan pola hidup, adat, dan pola pikir masyarakatnya yang akan menggambarkan pentingnya nilai-nilai rumah panjang terutama dilihat dari sisi edukasi dan sosialnya.
\end{abstract}

Kata Kunci: Suku Dayak, rumah panjang, Kalimantan, edukasi, vernakular

\begin{abstract}
Long house is a vernacular architecture form in Dayak tribes at Borneo. In this time, long house middle face modernization current and longer on the wane the total. In everyday life, long house is place for Dayak tribe does all activity with, interacted, learn from the older and demote various traditional wisdom, indigenous knowledge of Dayak tribes. In a word, long house is the centre of all social activity, culture, education, economy and dayaks tribe society policies. Long house is the culture centre for Dayak tribes society. So it mean long house is the heart of Dayak tribes society. Troubleshoot that studied long house related to alive pattern, custom, and the society patterned thinking that will describe the important long house values especially be seen from education side and the social.
\end{abstract}

Keyword: Dayak tribe, long house, Borneo, education, vernacular 


\section{LATAR BELAKANG}

Seperti apa yang di kemukakan oleh Rapoport dalam Luna 1993, apa yang dihasilkan manusia itu terbentuk karena latar belakang sosial budaya manusianya atau kondisi sosial manusianya. Bangunan Vernakular ataupun Arsitektur Vernakular, merupakan hasil dari kebudayaan manusia, yang biasanya berupa rumah tinggal. Kata vernacular/vernakular digunakan untuk menyebut bangunan yang sudah teruji dan tanggap/menyatu terhadap lingkungan sekitarnya termasuk tumbuh-tumbuhan dan hewan-hewan, secara empiri dapat dilihat dari pengunaan material yang berasal dari alam.

Arsitektur vernakular terbentuk oleh adanya ikatan manusia terhadap alam dalam rangka mewadahi aktifitas manusia yang diturunkan dari waktu ke waktu dan dari generasi ke generasi. Dari sekian banyak bangunan arsitektur vernakular yang ada, salah satunya adalah arsitektur vernakular masyarakat Dayak di Kalimantan, yang merupakan suku asli di pulau Kalimantan.

Rumah Panjang merupakan bentuk arsitektur vernakular yang khas dari masyarakat suku Dayak di Kalimantan Barat. Sebutan Rumah Panjang ini sudah sangat melekat di dalam benak masyarakat umum, dikarenakan rumah masyarakat suku dayak ini, sangat identik dengan bentuknya yang panjang.
Selain bentuknya yang memanjang juga sangat identik dengan sistem bangunan panggung.

Dalam kehidupan sehari-hari, rumah panjang merupakan tempat bagi suku Dayak melakukan segala aktivitas bersama, berinteraksi, belajar kepada kaum tua dan menurunkan berbagai kebijaksanaan tradisional (traditional wisdom), pengetahuan asli (indigenous knowledge) orang Dayak. Secara singkat, rumah panjang adalah pusat segala aktivitas sosial, budaya, edukasi, ekonomi dan politik masyarakat suku Dayak. Rumah panjang adalah pusat kebudayaan bagi masyarakat suku Dayak. Maka Rumah panjang merupakan jantung kehidupan masyarakat suku Dayak.

Saat ini rumah panjang tengah menghadapi arus modernisasi dan semakin lama semakin berkurang jumlahnya. Bergesernya pola pemukiman dari pola bermukim di rumah pajang secara bersamasama menjadi pola bermukim ke rumah-rumah tunggal, pada saat ini juga memberikan kontribusi terhadap berkurangnya keberadaan rumah panjang itu sendiri .

\section{PERMASALAHAN}

1. Bagaimana keberadaaan rumah panjang dalam peranannya sebagai pusat kebudayaan masyarakat suku Dayak di Kalimantan Barat? 
2. Bagaimana rumah panjang sebagai pusat kegiatan edukasi dan sosial masyarakat suku Dayak di Kalimantan Barat?

\section{TUJUAN}

Tujuan penelitian ini untuk mengetahui nilai-nilai penting dari sebuah bangunan vernacular, dalam hal ini Rumah Panjang suku Dayak di Kalimantan Barat terutama ditinjau dari nilai edukasi dan sosial.

\section{METODE PEMBAHASAN}

Metode pembahasan yang digunakan dalam kajian ini bersifat kualitatif untuk melihat hubungan rumah panjang dengan konsep dan filosofi nilai-nilai spiritual suku Dayak terutama dilihat dari nilai edukasi dan sosialnya bagi masyarakat suku Dayak di Kalimantan Barat.

Mengingat kompleksitasnya penelitian dan terbatasnya waktu, mengakibatkan penulis menggunakan studi pustaka untuk mempelajari nilai-nilai penting dan filosofis rumah panjang bagi suku Dayak terutama yang berkaitan dengan nilai edukasi dan sosial dari rumah panjang.

\section{TINJAUAN PUSTAKA}

Pola permukiman merupakan lingkup penyebaran daerah tempat tinggal penduduk menurut keadaan geografi (fisik) tertentu (Jayadinata, 1986), seperti permukiman sepanjang pantai, laut, aliran sungai dan jalan biasanya berbentuk linear, ataupun permukiman yang terdiri dari rumah-rumah yang satu sama lain letaknya berjauhan karena tanah pertaniannya luas, tetapi masih mengelompok dengan membentuk pola bujur sangkar.

Rapoport (1969) menyatakan bahwa bangunan vernakular dapat dikenali melalui proses bagaimana bangunan tersebut dirancang dan dibangun. Bentukan persegi dan lingkaran memiliki keterkaitan dengan mistis, kepercayaan, dan budaya penghuninya. Penggunaan bentukan selain lingkaran dalam suatu bangunan disebabkan oleh kebutuhan akan orientasi kosmik. Hunian awalnya dibangun bukan mengarah kepada pembuat atau kemampuan membuatnya tetapi lebih kepada pembangunan masyarakat (sosial dan spritual).

Turner (1972: 164) mengungkapkan bahwa rumah mempunyai berbagai macam fungsi dan semua fungsi itu tergantung pada tujuan yang ingin dicapai yang berbeda antara satu dengan lainnya tergantung pada tempat dan waktu.

Nguyen Van Huyen (Sumalyo, 2001) mengelompokkan arsitektur rumah panggung di Asia Tenggara berdasarkan kriteria bentuk melingkar, segi empat, bujur sangkar dll, dikaitkan dengan adat istiadat pola hidup 
maupun kepercayaan penghuninya (aspek antropologis).

\section{PEMBAHASAN}

Sebelumnya perlu diketahui, bahwa Suku Dayak merupakan suku yang memiliki banyak pembagian sub sukunya, di pulau Kalimantan yaitu mencapai 405 sub suku, menurut J. U. Lontaan, 1975, yaitu terdiri dari 6 suku besar dan 405 sub suku kecil. Meskipun terbagi dalam ratusan sub-etnis, semua etnis Dayak memiliki kesamaan ciri-ciri budaya yang khas. Ciri-ciri tersebut menjadi faktor penentu apakah suatu subsuku di Kalimantan dapat dimasukkan ke dalam kelompok Dayak. Ciriciri tersebut adalah rumah panjang, hasil budaya material seperti tembikar, mandau, sumpit, beliong (kampak Dayak), pandangan terhadap alam, mata pencaharian (sistem perladangan), dan seni tari.

Dewasa ini suku bangsa Dayak terbagi dalam enam rumpun besar, yakni: Apokayan (Kenyah-Kayan-Bahau), Ot Danum-Ngaju, Iban, Murut, Klemantan dan Punan. Rumpun Dayak Punan merupakan suku Dayak yang paling tua mendiami pulau Borneo. Sementara rumpun Dayak yang lain merupakan rumpun hasil asimilasi antara Dayak punan dan kelompok proto melayu ( Moyang Dayak yang berasal dari Yunnan ) dari Yunnan. Keenam rumpun itu terbagi lagi dalam kurang lebih 405 sub-etnis.

\section{Rumah Panjang}

Bangunan tempat tinggal atau Rumah tradisional orang Dayak disebut Rumah Panjang / betang atau lamin yakni sebuah Rumah yang berbentuk memanjang terdiri dari puluhan bilik. Hampir semua Orang Dayak kecuali Dayak Punan dan Dayak Meratus, mempunyai rumah panjang di masa lampau. Semua material rumah panjang dibuat dari kayu keras seperti kayu ulin atau belian. Mulai dari sirap ( atap kayu ),tiang, rangka, dinding, lantai hingga tangga.

Pola pemukiman Rumah Panjang erat hubungannya dengan sumber-sumber makanan yang disediakan oleh alam sekitarnya, seperti lahan untuk berladang, sungai yang banyak ikannya, dan hutan-hutan yang banyak dihuni oleh binatang buruan.

Rumah Panjang awalnya terbentuk dari satu keluarga. Kemudian mekar beranak-pinak secara turun temurun sehingga terbentuklah suatu komunitas yang lebih besar. Komunitas tersebut sangat sulit terpisahkan, terutama karena faktor darah, adat, kepercayaan, mata pencarian, dan faktor psikologis lainnya.

Rumah Panjang merupakan sebuah hunian yang memiliki arti lebih dari sekedar bentuknya. Bagi masyarakat Dayak Rumah Panjang tidak saja sekadar ungkapan legendaris kehidupan nenek moyang, melainkan juga suatu pernyataan secara utuh dan konkret tentang pamong desa, organisasi 
sosial serta sistem kemasyarakatan, sehingga tak pelak menjadi titik sentra dinamika kehidupan warganya.

Rumah Panjang merupakan lambang ikatan kekerabatan, kesatuan dan kebersamaan,merupakan warisan dari nenek moyang yang tidak ternilai harganya. Rumah Panjang terbentuk berdasarkan kebutuhan ruang untuk menampung kegiatan-kegiatan yang dilakukan oleh masyarakat Dayak.

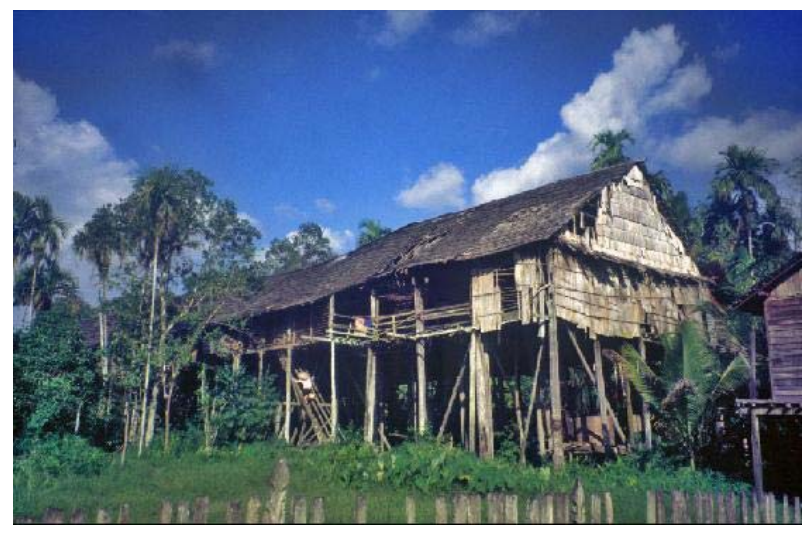

Gbr.I.1 Rumah Panjang Suku Dayak Taman ( di Kalimantan Barat )

Sumber: http:// google.com/search/

Orang Dayak biasanya berkumpul dalam jumlah puluhan maupun ratusan orang dalam berbagai kegiatan seperti pelaksanaan pesta perkawinan, upacara kematian, pertemuan perundingan ,ataupun acara tutup tahun (pesta sehabis panen). Semuanya tentunya membutuhkan ruangan-ruangan yang luas karena biasanya acara-acara tersebut tidak hanya dihadiri oleh penghuni Rumah Panjang tersebut, tetapi juga melibatkan kampungkampung atau desa di sekitar Rumah Panjang tersebut.
Disini terlihat jelas peranan penting Rumah Panjang dalam penyelenggaraan upacara-upacara adat dan juga menunjukkan nilai-nilai penting Rumah Panjang dalam tatanan sosial dan kemasyarakatan, dimana proses pelaksanaan upacara adat ini tidak hanya membutuhkan proses musyawarah tetapi juga adanya rasa kebersamaan, gotong royong dan saling berbagi serta saling menghormati.

Membangun Rumah Panjang tidak sembarangan, tetapi melalui berbagai rentetan upacara adat dan memperhatikan berbagai pantangan mulai dari mempersiapkan bahan sampai pada selesainya bangunan Rumah dan diresmikan pemakaiannya. Setiap sub suku masyarakat Dayak memiliki cara yang berbeda-beda dalam proses mendirikan Rumah Panjang yang disesuaikan dengan adat-istiadat dan kepercayaan daerah tersebut.

Bentuk dan besar Rumah Panjang ini bervariasi di berbagai tempat. Ada Rumah Panjang yang mencapai panjang 150 meter dan lebar hingga 30 meter. Umumnya Rumah Panjang di bangun dalam bentuk panggung dengan ketinggian tiga sampai lima meter dari tanah. Tingginya bangunan Rumah Panjang ini untuk menghindari datangnya banjir pada musim penghujan yang mengancam daerahdaerah di hulu sungai di Kalimantan. Beberapa unit pemukiman bisa memiliki Rumah Panjang lebih dari satu buah tergantung dari besarnya rumah tangga anggota komunitas hunian 
tersebut. Setiap rumah tangga (keluarga) menempati bilik (ruangan) yang di sekat-sekat dari rumah Panjang yang besar tersebut, di samping itu pada umumnya suku Dayak juga memiliki rumah-rumah tunggal yang dibangun sementara waktu untuk melakukan aktivitas perladangan, hal ini disebabkan karena jauhnya jarak antara ladang dengan tempat pemukiman penduduk.

Lebih dari bangunan untuk tempat tinggal suku dayak, sebenarnya Rumah Panjang adalah jantung dari struktur sosial kehidupan orang Dayak. Budaya Rumah Panjang merupakan cerminan mengenai kebersamaan dalam kehidupan sehari-hari orang Dayak. Di dalam Rumah Panjang ini setiap kehidupan individu dalam rumah tangga dan masyarakat secara sistematis diatur melalui kesepakatan bersama yang dituangkan dalam hukum adat. Keamanan bersama, baik dari gangguan kriminal atau berbagi makanan, suka-duka maupun mobilisasi tenaga untuk mengerjakan ladang.

Rumah Panjang memberikan makna tersendiri bagi penghuninya dimana Rumah Panjang memberikan gambaran keakraban hubungan dalam keluarga dan juga pada masyarakat. Selain itu, Rumah panjang juga memperkuat kesatuan dalam kegiatan ekonomi dimana sistem kerja "beduruk" dan "besaup" (gotong royong) lebih mudah di lakukan.
Nilai utama yang menonjol dalam kehidupan di Rumah Panjang adalah nilai kebersamaan (komunalisme) di antara para warga yang menghuninya, terlepas dari perbedaan-perbedaan yang mereka miliki.

Dalam kehidupan komunal yang demikian segala tindakan dan tingkah laku, selalu diarahkan pada suatu kerja sama dan sifat kekeluargaan sehingga antara tanggung jawab individu dari setiap keluarga dan tanggung jawab bersama dalam kelompok tidak jauh berbeda.

Dengan adanya nilai kebersamaan (komunalisme) pada Rumah Panjang, menumbuhkan sikap untuk saling menghormati dan menghargai serta dari sini juga dapat diketahui bahwa suku Dayak adalah suku yang menghargai suatu perbedaan.

Roedy Harjo Widjojo AMZ dalam " Masyarakat Dayak Menatap Hari Esok ” dalam Laporan Pendataan Rumah Adat Kalbar,2008. Ia mengatakan bahwa "...Rumah Panjang awalnya terbentuk dari satu keluarga. Kemudian mekar beranak-pinak secara turun temurun sehingga terbentuklah suatu komunitas yang lebih besar......."

Hal ini lah yang membuat arsitektur pada Rumah Panjang di Kalimantan Barat menjadi sangat unik dilihat dari proses pembangunannya yang secara bertahap.

Terdapat dua faktor yang mempengaruhi bentuk Rumah Panjang, yaitu : 
alam dan kebudayaan. Hal tersebut dapat kita lihat dari perubahan bentuk tempat tinggal masyarakat dayak. Berikut ini tahap terbentuknya Rumah Panjang masyarakat Dayak (dalam Laporan Pendataan Rumah Adat Kalimantan Barat.2008) :

1. Pada zaman prasejarah, ketika manusia belum menemukan teknologi untuk membuat rumah, manusia menempati goagoa sebagai tempat untuk bernaung. Goagoa tersebut berfungsi sebagai tempat untuk melindungi dirinya dari pengaruh alam, seperti panas, hujan, serangan binatang buas dll.

2. Tahap Kedua

Tahap dimana manuasia sudah mulai menemukan suatu teknologi untuk membuat rumah tinggal. Dalam sejarah masyarakat Dayak, pada masa ini mereka menempati rumah tinggal sederhana yang disebut Langkau. Langkau merupakan rumah tinggal yang ditempati oleh satu keluarga kecil untuk menghindari serangan dari binatang buas, maka masyarakat Dayak membuat rumah dengan tiang yang tinggi.

3. Tahap Ketiga

Perkembangan jumlah anggota kelurga / jumlah pengghuni membuat rumah langkau semakin sempit sehingga diperlukan suatu ruangan yang cukup besar. Pada tahap ini masyarakat Dayak membuat suatu rumah dengan ruangan yang besar yang disebut rumah Balai. Balai dihuni oleh satu kelurga besar yaitu orangtua dengan anak-anaknya.

4. Tahap Keempat

Pertumbuhan usia membuat anak-anak yang menghuni rumah balai semakin dewasa dan membentuk suatu keluarga sendiri. Rumah Balai sudah tidak memungkinkan untuk dihuni oleh beberapa keluarga. Kemudian dibuatlah suatu ruangan lain disamping rumah balai. Kondisi ini berkelanjutan sehingga terbentuklah beberapa ruangan di samping ruangan inti / utama.

Rumah yang terdiri dari beberapa ruangan 2 - 10 ruang, dinamakan Rumah Dampak. Rumah Dampak memiliki ruangan inti yaitu ruang yang dihuni oleh orangtua dan anak-anak yang belum menikah. Orangtua berfungsi sebagai pemimpin ( pun rumah ) dan penasehat ( tuai rumah ). Ruang utama terletak di tengah-tengah rumah. Satu ruang dinamakan bilik / lawang.

5. Tahap Kelima

Penghuni rumah dampak menjadi sangat sulit dipisahkan karena mereka berasal dari satu keluarga. Setiap keluarga baru menghasilkan anak yang kemudian bertambah dewasa dan membentuk keluarga baru. Setiap keluarga baru membuat satu ruangan baru di samping 
rumah. Rumah Dampak semakin bertambah panjang. Terdiri dari puluhan sampai ratusan bilik. Karena bentuk rumah yang memanjang sehingga dinamakan Rumah Panjang atau dalam bahasa Dayak dinamakan Rumah Panjai ( Dayak Iban ).

Perang antar suku semakin menambah alasan mengapa kelompok tersebut sangat sulit terpisahkan. Perlunya persatuan dalam mempertahankan kelompok dari serangan kelompok lain sehingga memungkinkan suatu Rumah Panjang bergabung dengan Rumah Panjang lainnya. Sehingga akan terdapat beberapa keluarga yang tergabung dalam suatu komunitas rumah panjang.

\section{Orientasi Rumah Panjang}

Pada umumnya orientasi Rumah Panjang masyarakat Dayak memanjang mengikuti alur sungai di mana mereka berada.
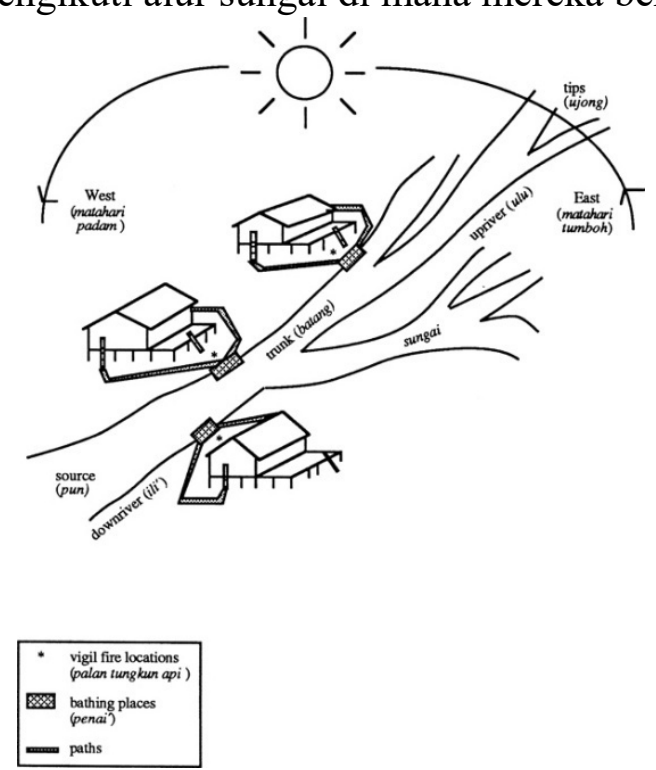

Gbr.I.2. Orientasi Rumah Panjang

Sumber: http:// epress.anu.edu.au/austronesians
Namun bagi masyarakat Dayak Iban, matahari memiliki nilai-nilai mistik tertentu.

Bagi masyarakat suku Dayak Iban orientasi rumah panjang harus menghadap ke arah matahari terbit dan membelakangi arah matahari terbenam. Arah orientasi utaraselatan selalu dihindari. Apabila orientasi rumah panjang menghadap ke arah utara atau selatan, maka sinar matahari akan membelah bubungan atap dari rumah panjang. Hal ini dipercaya dapat mendatangkan pengaruh yang tidak baik terhadap para penghuni rumah panjang. Pengaruh tersebut misalnya para penghuni rumah panjang akan tertimpa penyakit dan lain-lain.

Terkait dengan orientasi secara umum dimana Rumah panjang yang dibangun selalu menghadap ke sungai, memanjang paralel atau searah panjang sungai, orientasi dan kedekatan dengan sungai dikarenakan sungai telah menjadi sebuah sistem sosial-budaya dan ekonomi bagi masyarakat Dayak. Sungai memberikan multifungsi bagi mereka, yaitu sebagai sarana transportasi dan komunikasi, sumber ikan, tempat mandi dan mencuci.

Selain karena sungai sebagai sarana multifungsi, orientasi yang mengikuti atau searah panjang sungai juga sebagai antisipasi pertambahan panjang Rumah Panjang bagi penghuni atau keluarga baru yang membuat bilik disamping bangunan. 


\section{Nilai penting Rumah Panjang}

Di dalam rumah panjang tidak terdapat batas yang jelas antara ruang-ruangnya. Karena pada dasarnya setiap ruang selalu diperuntukkan untuk bersama. Namun bagaimanapun bentuk ruangnya selalu terdapat area publik, semi publik, dan area private dalam setiap rumah panjang.

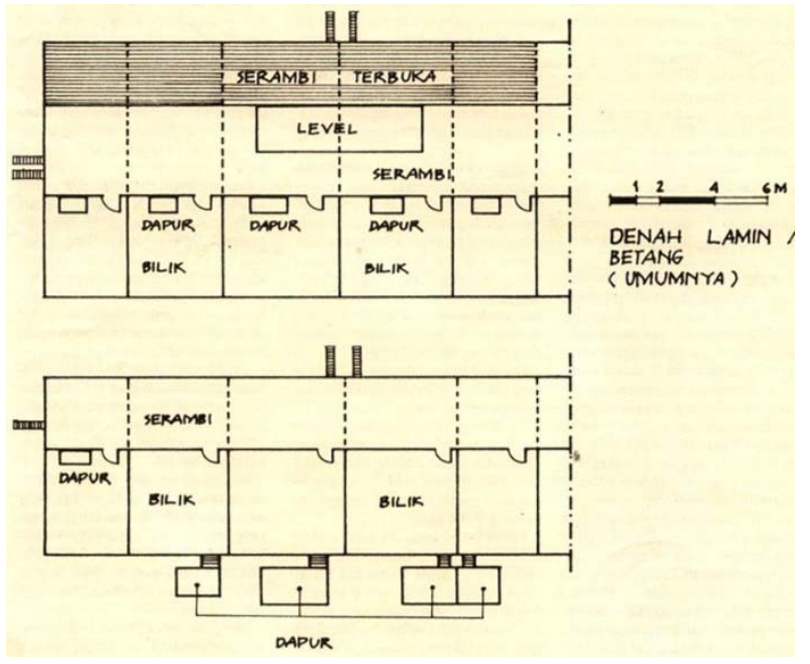

Gbr.I.1 Denah Rumah Panjang pada suku Dayak umumnya.

Adat-istiadat tersebut bersumber dari kebiasaan dan lama-kelamaan menujadi suatu aturan yang harus ditaati oleh semua penghuni rumah panjang. Adat-istiadat dan kebiasaan tersebut telah membentuk individu-individu yang tinggal di rumah panjang untuk berlaku sopan-santun dan menghormati siapa saja.

Adat-istiadat tersebut sekaligus memberi isyarat tentang apa yang boleh dan tidak boleh dilakukan dan bagaimana seharusnya bertingkah laku. Misalnya bagaimana sikap kita bertamu pada malam hari, bagaimana sikap kita apabila ada tamu, dll. Kesemuanya itu seolah-olah memberi batas ruang maya namun setiap orang tahu batas itu. Demikian juga dalam mendirikan rumah panjang dilakukan dengan cara gotong-royong dalam bahasa Dayak desa dikenal dengan istilah beduruk. Dalam gotong-royong tersebut biasanya mengundang masyarakat dari desa tetangga dan disertai dengan pesta-pesta.

\section{Nilai edukasi pada Rumah Panjang}

Suku bangsa Dayak tidak mengenal tulisan atau aksara. Oleh sebab itu tradisi lisan merupakan tradisi yang mereka wariskan secara turun temurun dari nenek moyang mereka. Salah satu ciri tradisi lisan adalah komunikasi dan penyampaian informasi secara lisan dan menyampaikannya dari mulut ke mulut.

Syarat utama bagi masyarakat yang memiliki tradisi lisan, mereka harus memiliki daya ingat yang baik (brilian), kesetiaan, dan kejujuran. Misalnya cara membina seseorang untuk menjadi seorang belian (dukun) adalah dengan cara menghafalkan kata, kalimat, mantera-mantera dari senior/gurunya secara lisan bukan dengan tulisan. Sistem nilai dan norma pun mereka wariskan dari tradisi yang mereka miliki. Tanda-tanda tentang gejala alam seperti hujan, panas, banjir, bahaya penyakit, tanda sial, keberuntungan, semuanya bisa dibaca melalui suara atau karakter 
binatang, posisi bintang dan bulan, keadaan tanah, warna daun, mimpi, garis tangan, tahi lalat, dan lain-lain.

Demikian juga dengan pengetahuan mereka tentang zat-zat dan racun dari akarakaran dan pohon-pohon yang bisa digunakan untuk obat tradisional dan untuk senjata.

Sistem kalender yang mereka gunakan sangat berbeda dari sistem kalender nasional. Sistem bulan dan bintang dilangit berbeda waktunya dari kalender nasional. Itulah kalender yang mereka gunakan untuk mengatur kegiatan pertanian dan kegiatan berburu dan menangkap ikan. Bahkan bulan untuk pernikahanpun disesuaikan dengan posisi bulan dilangit. Satuan waktu dan bilanganpun memiliki istilah-istilah tersendiri.

\section{Kesimpulan}

Dalam kehidupan sehari-hari, Rumah Panjang merupakan tempat bagi suku Dayak melakukan segala aktivitas bersama, berinteraksi, belajar kepada kaum tua dan menurunkan berbagai kebijaksanaan tradisional (traditional wisdom), pengetahuan asli (indigenous knowledge) suku Dayak.

Dilihat dari sisi edukasi, hal yang menjadikan peranan Rumah Panjang menjadi penting karena suku Dayak tidak mengenal tulisan atau aksara. Oleh sebab itu tradisi lisan merupakan tradisi yang mereka wariskan secara turun temurun dari nenek moyang mereka. Salah satu ciri tradisi lisan adalah komunikasi dan penyampaian informasi secara lisan dan menyampaikannya dari mulut ke mulut. Demikianlah pengalaman, pengetahuan dan keterampilan di wariskan secara lisan kepada generasi penerusnya. Disini proses kebersamaan ( komunalisme) di Rumah Panjang terlihat signifikan dalam proses pembelajaran kebijaksanaan tradisional (traditional wisdom) dan pengetahuan asli (indigenous knowledge) masyarakat Dayak.

Dilihat secara nilai sosial, ada beberapa hal penting sebagai berikut :

- Di dalam Rumah Panjang ini setiap kehidupan individu dalam rumah tangga dan masyarakat secara sistematis diatur melalui kesepakatan bersama yang dituangkan dalam hukum adat.

- Rumah Panjang juga memberikan gambaran keakraban hubungan dalam keluarga dan juga pada masyarakat.

- Selain itu, Rumah panjang juga memperkuat kesatuan dalam kegiatan ekonomi dimana sistem kerja "beduruk" dan "besaup" (gotong royong) lebih mudah di lakukan.

- Demikian juga dalam proses penyelenggaraan upacara-upacara adat, nilai kebersamaan melalui musyawarah dan gotong royong jelas terlihat.

Disini terlihat jelas peranan penting Rumah Panjang bagi suku Dayak terutama tatanan 
nilai- nilai sosial dan kemasyarakatan yang berkembang bersama nilai kebersamaan ( komunalisme) terlepas dari perbedaanperbedaan yang ada, yang menumbuhkan rasa kebersamaan serta sikap saling menghormati dan saling menghargai.

Secara singkat, rumah panjang adalah pusat segala aktivitas sosial, budaya, edukasi, ekonomi dan politik masyarakat suku Dayak. Rumah panjang adalah pusat kebudayaan bagi masyarakat suku Dayak. Maka Rumah panjang merupakan jantung kehidupan masyarakat suku Dayak.

Rumah panjang selain sebagai tempat kediaman juga merupakan pusat segala kegiatan tradisional warga masyarakat.

\section{DAFTAR PUSTAKA} . 2008. Laporan Pendataan Rumah Adat Dayak Kalimantan Barat. PU Provinsi Kalimantan Barat

Dewi, Ni Ketut A. 2003. Wantah Geometri, Simetri dan Religiusitas pada Rumah Tinggal Tradisional di Indonesia. Jurnal Permukiman "Natah", Vol. 1, Pebruari 2003: 29-43.
Djuweng, Stephanus. (ed). 1996. Manusia Dayak: Orang Kecil yang Terperangkap Modernisasi. Institute of Dayakology Research and Development. Pontianak.

Fox, James. J. 2006. Inside Austronesian Houses. ANU E Press. Australia.

Geddes. W. R. 1958. Nine Dayak Nights. Journal of the Polynesian Society: Reviews. Vol. 67, No. 3, p 306-316.

Oliver, Paul. 1987. Dwellings: The House Across the World. Phaidon Press Limited.

Pebriano, V. 2006. Tesis S2 Budaya Bermukim Masyarakat Dayak Dosan di Kalimantan Barat. Mandiri. Bandung.

Praptantya, D. BSE dan Kasniyah, N. 2003. Fungsi dan Makna Pantak bagi Masyarakat Kanayatn. Sosiohumanika, 16B (1). Januari 2003: 79-85.

Rapoport, Amos. 1969. House Form and Culture. PRENTICE-HALL, INC., Englewood Cliffs, New York.

Rapoport, Amos. 1976. Human Aspects of Urban Form: Towards a ManEnvironment Approach to Urban Form and Design. Pergamon Press. 
Ronald, Arya. (ed). 2008. Kekayaan dan Kelenturan Arsitektur. Muhammadiyah University Press. Surakarta. 